Arq. Bras. Med. Vet. Zootec., v.70, n.4, p.1120-1128, 2018

\title{
Mastitis in the transition period: identification of potential blood markers
}

\author{
[Mastite no período de transição: identificação de potenciais marcadores no sangue] \\ K.R. Santos $^{1 *}$, F.N. Souza ${ }^{1}$, M.G. Blagitz ${ }^{1}$, C.F. Batista ${ }^{1}$, H.G. Bertagnon ${ }^{1,2}$, R.C. Gomes ${ }^{1}$, \\ P.C.C. Molinari ${ }^{1}$, S.A. Diniz ${ }^{3}$, M.X. Silva ${ }^{3}$, J.P.A. Haddad ${ }^{3}$, \\ M.B. Heinemann ${ }^{1}$, A.M.M.P.D. Libera ${ }^{1}$ \\ ${ }^{1}$ Universidade de São Paulo - São Paulo, SP \\ ${ }^{2}$ Universidade Centro Oeste do Paraná - UNICENTRO - Guarapuava, PR \\ ${ }^{3}$ Escola de Veterinária - UFMG - Belo Horizonte, MG
}

\begin{abstract}
This study identified potential blood markers associated with mastitis in dairy cows under different dry therapies during the transition period, using a logistic regression model. Thirty-four Holstein dairy cows were divided into three groups: untreated controls (13 cows, 42 quarters); animals that received an antimicrobial at drying-off (10 cows, 40 quarters); and animals that were administered an internal teat sealant at drying-off (11 cow, 44 quarters). Blood and quarter milk samples were collected 60 days before the expected day of calving, on the day of calving, and three, seven, 15, 21, and 30 days after calving. Milk samples were submitted for bacteriological analysis and somatic cell count. Blood samples were collected for analyses of the following: the erythrogram and leucogram; plasm fibrinogen concentration; hepatic and renal functions; metabolic profile; serum calcium and phosphorous levels; total serum protein and albumin concentrations. The concentration of total serum proteins was associated with a high somatic cell count. Similarly, the concentrations of total serum proteins and triglycerides were associated to milk bacteriological positive samples during the transition period. Thus, the occurrence of mastitis in dairy cows during the transition period was greater in animals that showed higher concentrations of serum total proteins and triglycerides, in contrast to the use of dry cow therapy.
\end{abstract}

Keywords: intramammary infection, risk factor, drying-off, periparturient period, metabolism

\section{RESUMO}

O presente estudo identificou potenciais marcadores sanguíneos associados tanto à mastite, durante o período de transição em vacas leiteiras submetidas à antimicrobianoterapia, quanto à utilização do selante interno de teto na secagem por modelo de regressão logística. Trinta e quatro vacas da raça Holandesa foram divididas em três grupos experimentais, a saber: 13 animais (42 quartos mamários) que não receberam tratamento na secagem; 10 animais (40 quartos mamários) tratados por via intramamária com uma bisnaga do antimicrobiano para vaca seca à base de cefalônio anidro após a última ordenha em cada quarto mamário; $e$ 11 animais (44 quartos mamários) que receberam, por via intramamária, uma bisnaga de selante à base de subnitrato de bismuto após a última ordenha em cada quarto mamário. As amostras de leite e sangue foram coletadas 60 dias antes da data prevista do parto, na secagem, e no dia do parto e após três, sete, 15 e 21 dias após o parto. As amostras de leite foram utilizadas para o exame microbiológico e a determinação da contagem de células somáticas. As amostras de sangue foram utilizadas para determinação do eritrograma, leucograma, fibrinogênio plasmático, funções hepáticas e renais, perfil metabólico, proteína total e albuminas séricas e concentração sérica de cálcio e fósforo. A concentração total de proteínas séricas foi associada à alta contagem de células somáticas. Similarmente, a concentração total de proteínas séricas e triglicérides foi associada a isolamento de patógenos causadores de mastite nas amostras de leite durante o período de transição. Desse modo, conclui-se que vacas leiteiras com concentrações séricas maiores de proteína total e triglicérides têm maior chance de apresentar mastite durante o período de transição; em contraste, o uso da antimicrobianoterapia de vaca seca reduz esse risco.

Palavras-chave: infecção intramamária, fator de risco, secagem, período periparturiente, metabolismo

Recebido em 24 de maio de 2017

Aceito em 22 de novembro de 2017

*Autor para correspondência (corresponding author)

E-mail: kareiss@usp.br 


\section{INTRODUCTION}

The transition period is characterized by sudden changes in metabolic and immune functions (Bertoni and Trevisi, 2013; Sordillo, 2016) that play a critical role in the maintenance the cow's health. Thus, dairy cows experience the most episodes of infectious diseases and metabolic disorders during this period. Among the infectious diseases, mastitis is the most common and costly (Sepúlveda-Varas et al., 2015).

Alterations during the transition period result in intense lipid mobilization, a decrease in glucose levels, and a drastic increase in non-esterified fatty acids (NEFA) and $\beta$-hydroxybutyrate (BHBA) levels (Bertoni and Trevisi, 2013). Furthermore, large variations in several blood parameters occur during the transition period including hematological values, total protein, globulin, albumin, fibrinogen, cholesterol, lowdensity lipoprotein (LDL), high-density lipoprotein (HDL), triglycerides, and phosphorous and calcium levels; and renal and hepatic functions (Piccione et al., 2011; Piccione et al., 2012; Todorovic and Davidovic, 2012; Bertoni and Trevisi, 2013; Kurpinska et al., 2015). Therefore, blood analysis during the transition period may be useful as a strategic tool in decreasing the overwhelming risks (Bertoni and Trevisi, 2013).

In face of, a better understanding of conditions associated with mastitis can assist in diagnosis and control to maximize milk production from dairy cows and increase profitability of the milk supply. Thus, we monitored blood markers in dairy cows during the transition period and identify those that were associated with mastitis under different dry therapy strategies.

\section{MATERIAL AND METHODS}

This research complied with the Ethical Principles in Animal Research and was approved by the Ethics Committee of the Faculty of Veterinary Medicine and Animal ScienceUniversity of São Paulo (protocol number 9945030214)

Thirty-four healthy Holstein cows with an average daily milk yield of $19.59 \pm 0.99 \mathrm{~L}$ in the last month of lactation and $6.29 \pm 0.22$ years of age were included in the study. Dairy cows with other clinical visible signs of non-related diseases are not included in the present study. During the dry period, dairy cows were fed with corn silage as roughage, whereas during the rainy season they were maintained in a rotating pasture system with Tanzania grass (Panicum maximum cv. Tanzania). They also received soybean meal, wheat bran, and corn meal as a protein concentration of $20 \%$, as well as vitamin and mineral supplements.

The cows were divided into three groups: 13 animals did not receive any dry cow treatment; 10 animals were treated with $250 \mathrm{mg}$ of anhydrous cephalonium (Cepravin ${ }^{\circledR}$, MSD, São Paulo, Brazil) in each mammary quarter after the last milking; and 11 animals were administered an internal teat sealant containing $65 \%$ bismuth in a paraffin base (TEAT SEAL ${ }^{\circledR}$, Zoetis, São Paulo, Brazil) also in each mammary quarter after the last milking.

Blood and milk samples were collected at seven time points: immediately before drying off (60 days before the expected day of calving) (D60); on the day of parturition (D0); and 3 (D3), 7 (D7), 15 (D15), 21 (D21), and 30 (D30) days after calving.

Blood samples were collected from the subcutaneous abdominal vein in tubes with EDTA to evaluate the erythrogram and leucogram and determine the plasma fibrinogen concentration. Blood was also collected in tubes with heparin to examine hepatic (alanine aminotransferase [ALT], aspartate aminotransferase [AST], and gamma glutamyltransferase [GGT)] and renal (urea and creatinine) functions, metabolic profiles (cholesterol, triglycerides, LDL, HDL, BHBA, and NEFA), serum calcium and phosphorous levels, total serum protein and albumin concentrations. Finally, blood was collected in tubes with fluoride to quantify the glucose level.

Erythrocytes were counted using a modified Neubauer hemocytometer and Gower's solution as a diluent. The following hematological parameters were determined: the packed cell volume, measured by the microhematocrit method; the hemoglobin concentration, established using the cyanmethemoglobin method; and the calculated blood indices, namely the mean corpuscular volume (MCV), mean 
corpuscular hemoglobin $(\mathrm{MCH})$, and mean corpuscular hemoglobin concentration (MCHC). Total leukocytes count was counted using a Neubauer's chamber, and the differential leukocyte count was obtained from routine blood smears (Jain, 1986).

The blood samples were centrifuged $250 \times g$ to obtain serum, and then the following measurements were obtained using commercial kits: ALT (Ref. 108, Labtest, Lagoa Santa, Brazil), AST (Ref. 109, Labtest, Lagoa Santa, Brazil), GGT (Ref. 105, Labtest, Lagoa Santa, Brazil), urea (Ref. 27, Labtest, Lagoa Santa, Brazil), creatinin (Ref. 35, Labtest, Lagoa Santa, Brazil), calcium (Ref. 90, Labtest, Lagoa Santa, Brazil), phosphorus (Ref. 42, Labtest, Lagoa Santa, Brazil), glucose (Ref. 133, Labtest, Lagoa Santa, Brazil), cholesterol (cat. no. CH3810, Randox, Crumlin, Ireland), triglycerides (cat. no. TR3823, Randox, Crumlin, Ireland), LDL (cat. no. CH3841, Randox, Crumlin, Ireland), HDL (cat. no. CH3811, Randox, Crumlin, Ireland), BHBA (cat. no. FA1007, Randox, Crumlin, Ireland), NEFA (cat. no. FA115, Randox, Crumlin, Ireland), and albumin (Ref. 19, Labtest, Lagoa Santa, Brazil). All analyses described above were performed using a Drake Quick Lab II semi-automatic biochemical analyzer (São José do Rio Preto, Brazil). The concentration of total serum protein was determined by refractometry as described by Kaneko et al. (2008), and the concentration of serum globulin was calculated by subtracting the value of albumin from that of total protein (Smith, 2014). The albumin to globulin $(\mathrm{A} / \mathrm{G})$ ratio was also calculated.

The plasm concentration of fibrinogen, based on the difference in protein content before and after heat treatment of plasma at $56^{\circ} \mathrm{C}$ for $3 \mathrm{~min}$, was estimated by refractrometry as described by Kaneko et al. (2008).

First, the strip cup test was performed to detect clots, flakes, or other abnormal secretions. Predipping, with one towel used for each teat, was then performed. After discarding the first three milk streams, teat ends were scrubbed with cotton soaked in $70 \%$ ethanol, and a single milk sample (approximately 4mL) was aseptically collected from each mammary quarter into sterile vials for bacteriological analysis. Finally, milk samples (about 40mL) for the evaluation of SCC were held at $4^{\circ} \mathrm{C}$ until their arrival in the laboratory. Milk samples for bacteriological analysis were stored at $-20^{\circ} \mathrm{C}$ for a maximum of 30 days until analysis.

The bacteriological analysis was performed through culture of $0.01 \mathrm{~mL}$ of each milk sample on $5 \%$ sheep blood agar plates. The plates were incubated for 72 hours at $37^{\circ} \mathrm{C}$, followed by Gram staining, observation of colony morphologies, and biochemical testing (Oliver $e t$ al., 2004). A milk sample was considered culture-positive when the growth of $\geq 3$ colonies was detected, with the exception of milk samples showing the growth of Staphylococcus aureus or Streptococcus agalactiae colonies, which were considered culture-positive when the growth of $\geq$ 1 colony was detected. Samples yielding colonies of $\geq 3$ different bacterial species were considered contaminated (Oliver et al., 2004).

Somatic cell counting was performed in duplicate, following the method described by Prescott and Breed (1910), and modified to use panoptic cell staining as described by Sarikaya $e t$ al. (2004).

The data were analyzed using STATA version 12 statistical software (Stata Corp., College Station, Texas, USA). A logistic regression model was used to analyze each blood variable and its association with bacteria-positive quarter milk samples or high milk SCCs $\left(>2 \times 10^{5}\right.$ cells $\mathrm{mL}^{-}$ ${ }^{1}$ ), as the threshold for SCC proposed by Schukken et al. (2003) for infected quarters. Because of the high SCC in colostrum even in healthy quarters (Sargeant et al., 2001), colostrum samples collected for SCC on the day of parturition were not included in the logistic regression model. Variables were first analyzed individually to determine the significance of associations and then in combination to assess the effect of a single variable on all others. In the first stage of the analysis, an unconditional logistical model for each variable related to bacteriological positive samples or high milk SCC, $P$-values $\leq 0.20$, variables that continued to the next stage of the analysis were considered eligible. In the final model, eligible variables were used to develop a final multivariate logistical model, with variables showing significant associations $(P \leq 0.05)$ retained in the model. 


\section{RESULTS}

The results of the bacteriological analysis are summarized in Table 1. The logistic regression model for high SCCs $\left(>2 \times 10^{5}\right.$ cells $\left.\mathrm{mL}^{-1}\right)$ was adjusted, with the following explanatory variables $(P \leq 0.20)$ included in the logistic regression analysis: time of sampling; treatment type; concentrations of total serum proteins, globulin, and albumin; $\mathrm{A} / \mathrm{G}$ ratio; fibrinogen, percentage of segmented neutrophils and eosinophils; number of eosinophils, levels of urea, NEFA, glucose, and LDL. In this model, only time of sampling, treatment type, and total serum proteins showed a statistically significant association $(P \leq 0.05)$ with having high milk SCC (Table 2). These variables remained in the final model.

A logistic regression model for milk bacteriological positive samples was adjusted, with the following explanatory variables $(\mathrm{P} \leq$ 0.20 ) included in the logistic regression analysis: time of sampling; treatment type; packed cell volume; MCHC; and levels of total proteins, albumin, urea, phosphorus, cholesterol, triglycerides, LDL, and HDL. In this model, only three variables (treatment type, total proteins, and triglycerides) were found to be statistically significantly associated $(P \leq 0.05)$ with bacteriologically positive milk samples (Table 3 ) and remained in the final model.

\section{DISCUSSION}

A better understanding of the conditions underlying the complex relationship between shifts in blood parameters and the occurrence of mastitis during the transition period is crucial to the diagnosis and control of this disease. Specific markers among these parameters may be a useful predictors of mammary gland health during this sensitive period for the cow (Rezemand et al., 2007; Moyes et al., 2009; Schwegler et al., 2013).

In this study, the total serum protein concentration was associated with a high SCC (> 200.000 cells $\left.\mathrm{mL}^{-1}\right)$. Similarly, the total serum protein concentration and trygliceride level were associated with bacteriological positive milk samples during the transition period. Although puzzling, widely studied parameters that are related to metabolic disorders during the peripartum period, i.e., BHBA, NEFA, and glucose (Rezamand et al., 2007; Moyes et al., 2009; Sordillo, 2016), were not regarded as markers of high milk SCC and bacteriological positive milk samples. In contrast, other variables such as serum total proteins, which can be easily and quickly measured in field conditions by refractometry, were found to be associated with mastitis during the transition period.

Previously, Rezamand et al. (2007) found that although NEFA and BHBA concentrations increased during parturition, as observed in this study (data not shown), were not associated with new intramammary infections (IMIs) during the post-partum period. Instead, Le Blanc et al. (2004) and Rezemand et al. (2007) suggested that new cases of IMIs were associated with a reduction in the concentration of cholesterol in plasma, probably because of a decrease in the liver's capacity to transport lipoproteins, which are responsible for transporting cholesterol. In this study, although cholesterol was a variable eligible to enter the logistic regression models, it was not found to be a statistically significant $(\mathrm{P}=$ $0.20)$ predictor in either final model.

On the other hand, in this study, the serum trygliceride concentration was considered a risk factor to bacteriological positive milk samples during the post-partum period. The pathogen isolation rate increased $2.1 \%$ per unit $\left(\mathrm{mg} \mathrm{dL}^{-1}\right)$ increase in serum tryglicerides. Interestingly, Kushibiki et al. (2002) studied the effect of tumor necrosis factor-alpha (TNF- $\alpha$ ) on the lipid metabolism of heifers, and they observed that infusion with recombinant TNF- $\alpha$ quickly increased their trygliceride concentrations 0.5 hours after infusion. Regarding that, TNF- $\alpha$ plays a key role in regulating an inflammatory immune response, and it mediates hypertriglyceridemia in response to infection (Bradford et al., 2009). Accordingly, cows with subclinical mastitis during the post-partum period have a TNF- $\alpha$ concentration four weeks before calving that is elevate in comparison with that of healthy cows (Dervishi et al., 2016), which corroborate with our findings. 
Table 1. Results of bacterial testing of milk quarter samples from dairy cows in the transition period

\begin{tabular}{|c|c|c|c|c|c|c|c|c|}
\hline & $\begin{array}{l}\text { Bacterial isolates } \\
\%(\mathrm{n})\end{array}$ & D60 & D0 & D3 & D7 & D15 & D21 & D30 \\
\hline \multirow{12}{*}{ GC } & Corynebacterium bovis & $9.62(5)$ & 0 & $2.08(1)$ & 0 & 0 & 0 & 0 \\
\hline & Klebsiella spp. & 0 & 0 & $2.08(1)$ & $1.92(1)$ & 0 & $1.96(1)$ & $1.92(1)$ \\
\hline & $\begin{array}{l}\text { Klebsiella spp. and Staphylococcus } \\
\text { haemolyticus }\end{array}$ & 0 & 0 & 0 & 0 & 0 & 0 & $1.92(1)$ \\
\hline & Staphylococcus aureus & 0 & $3.85(2)$ & $4.17(2)$ & 0 & 0 & 0 & $1.92(1)$ \\
\hline & S. aureus and Enterococcus spp. & $1.92(1)$ & 0 & 0 & 0 & 0 & 0 & 0 \\
\hline & Staphylococcus chromogenes & $1.92(1)$ & $1.92(1)$ & 0 & $1.92(1)$ & $2.27(1)$ & $5.88(3)$ & 0 \\
\hline & S. chromogenes and C. bovis & $1,92(1)$ & 0 & 0 & 0 & 0 & 0 & 0 \\
\hline & Staphylococcus epidermidis & $3.85(2)$ & $3.85(2)$ & $6.25(3)$ & $3.85(2)$ & $2.27(1)$ & $1.96(1)$ & $3.85(2)$ \\
\hline & S. epidermidis and $S$. chromogenes & 0 & 0 & 0 & $1.92(1)$ & 0 & 0 & 0 \\
\hline & S. epidermidis and E. coli & 0 & 0 & 0 & 0 & 0 & 0 & $1.92(1)$ \\
\hline & S. agalactiae and Pseudomonas spp & 0 & 0 & 0 & 0 & 0 & $1.96(1)$ & 0 \\
\hline & Streptococcus uberis & $1.92(1)$ & $3.84(2)$ & 0 & $1.92(1)$ & 0 & $1.96(1)$ & $1.92(1)$ \\
\hline \multirow[t]{9}{*}{ GA } & Negative & $\begin{array}{l}86.84 \\
(34)\end{array}$ & $95(38)$ & $97.5(39)$ & $95(38)$ & $92.5(37)$ & $92.5(37)$ & $92.5(37)$ \\
\hline & Contaminated & 0 & 0 & 0 & 0 & 0 & $2.50(1)$ & 0 \\
\hline & E. coli & 0 & 0 & 0 & 0 & 0 & 0 & $2.50(1)$ \\
\hline & Pseudomonas spp. & 0 & 0 & 0 & 0 & 0 & $5(2)$ & 0 \\
\hline & Pseudomonas spp. and S. epidermidis & 0 & 0 & 0 & 0 & 0 & 0 & $2.50(1)$ \\
\hline & S. aureus & $2.63(1)$ & 0 & 0 & 0 & $2.50(1)$ & $2.63(1)$ & 0 \\
\hline & S. epidermidis & $2.63(1)$ & 0 & 0 & $5(2)$ & $2.50(1)$ & 0 & 0 \\
\hline & S. epidermidis and S. haemolyticus & 0 & 0 & 0 & 0 & 0 & 0 & $2.50(1)$ \\
\hline & S. haemolyticus & $5.26(2)$ & $2.50(1)$ & 0 & 0 & 0 & 0 & 0 \\
\hline \multirow{16}{*}{ GS } & Klebsiella spp & 0 & 0 & 0 & 0 & 0 & $2.27(1)$ & 0 \\
\hline & Micrococcus spp & 0 & 0 & 0 & 0 & $2.27(1)$ & 0 & 0 \\
\hline & Pseudomonas spp & 0 & $2.27(1)$ & 0 & 0 & 0 & 0 & 0 \\
\hline & Pseudomonas spp and Klebsiella spp & 0 & 0 & $2.27(1)$ & 0 & 0 & 0 & 0 \\
\hline & S. aureus & $2.08(1)$ & $2.27(1)$ & $2.27(1)$ & $4.55(2)$ & $2.27(1)$ & $2.27(1)$ & 0 \\
\hline & S. chromogenes & $2.08(1)$ & 0 & 0 & $2.27(1)$ & 0 & $2.27(1)$ & $2.27(1)$ \\
\hline & S. epidermidis & $2.08(1)$ & $4.55(2)$ & $6.82(3)$ & $4.55(2)$ & $2.27(1)$ & $6.82(3)$ & \\
\hline & S. epidermidis and $S$. haemolyticus & 0 & 0 & 0 & 0 & 0 & $2.27(1)$ & 0 \\
\hline & S. epidermidis and Klebsiella spp & 0 & 0 & 0 & $2.27(1)$ & 0 & 0 & 0 \\
\hline & S. haemolyticus & $8.33(4)$ & $2.27(1)$ & $4.55(2)$ & 0 & 0 & $6.82(3)$ & $2.27(1)$ \\
\hline & S. haemolyticus and S. chromogenes & $4.17(2)$ & $2.27(1)$ & 0 & 0 & 0 & 0 & 0 \\
\hline & S. hyicus & 0 & $2.27(1)$ & 0 & 0 & 0 & 0 & 0 \\
\hline & Staphylococcus warneri & 0 & $2.27(1)$ & 0 & 0 & 0 & 0 & 0 \\
\hline & S. agalactiae & $2.08(1)$ & 0 & 0 & 0 & 0 & 0 & 0 \\
\hline & S. agalactiae and S. haemolyticus & $2.08(1)$ & 0 & 0 & 0 & 0 & 0 & 0 \\
\hline & S. uberis & 0 & $11.36(5)$ & $9.09(4)$ & 0 & 0 & 0 & 0 \\
\hline
\end{tabular}

D60 (60 days before the expected day of calving); D0 (day of parturition); D3 ( $3^{\text {rd }}$ day after calving); D7 ( $7^{\text {th }}$ day after calving); D15 (15 ${ }^{\text {th }}$ day after calving); D21 (21 $1^{\text {st }}$ day after calving); D30 (30 ${ }^{\text {th }}$ day after calving). GC: animals that did not receive any dry cow treatment; GA: animals that were treated with $250 \mathrm{mg}$ of anhydrous cephalonium in each mammary quarter after the last milking; and GS: animals that were administered an internal teat sealant containing $65 \%$ bismuth in a paraffin base in each mammary quarter after the last milking. 
Table 2. Final model $(\mathrm{P} \leq 0.05)$ of variables associated with high milk SCC $\left(>2 \times 10^{5}\right.$ cells $\left.\mathrm{mL}^{-1}\right)$ in the transition period

\begin{tabular}{ccc}
\hline Variable & $\begin{array}{c}\text { Odds ratio }(95 \% \text { confidence } \\
\text { interval })\end{array}$ & $P$ value \\
\hline Antimicrobial & $0.259(0.113-0.595)$ & 0.001 \\
D3 & $0.063(0.007-0.562)$ & 0.013 \\
D7 & $0.026(0.003-0.229)$ & 0.001 \\
D15 & $0.029(0.003-0.246)$ & 0.001 \\
D21 & $0.030(0.003-0.255)$ & 0.001 \\
D30 & $0.031(0.004-0.262)$ & 0.001 \\
Total protein & $1.964(1.181-3.267)$ & 0.009
\end{tabular}

SCC: somatic cell count; D3 ( $3^{\text {rd }}$ day after calving); D7 ( th $^{\text {th }}$ day after calving); D15 (15 ${ }^{\text {th }}$ day after calving); D21 $\left(21^{\text {st }}\right.$ day after calving); D30 (30 $0^{\text {th }}$ day after calving).

Table 3. Final model $(\mathrm{P} \leq 0.05)$ of variables associated with milk samples testing positive for bacteria in the transition period

\begin{tabular}{ccc}
\hline Variables & $\begin{array}{c}\text { Odds ratio }(95 \% \text { confidence } \\
\text { interval })\end{array}$ & $P$ value \\
\hline Antimicrobial & $0.371(0.175-0.787)$ & 0.01 \\
Total proteins & $1.632(1.019-2.615)$ & 0.04 \\
Tryglicerides & $1.021(1.003-1.039)$ & 0.02 \\
\hline
\end{tabular}

Furthermore, Souza et al. (2011) reported that animals infected with bovine leukemia virus (BLV) presented a higher triglyceride concentration than that found in healthy animals. In addition, Della Libera et al. (2015) related BLV-infected dairy cows infectious, particularly in cows with persistent lymphocytosis, to milk immune cell dysfunction. Dysfunction was especially apparent in neutrophils, which can be even more evident during the periparturient period, indicating their importance to mammary gland defense (Souza et al., 2012). Altogether, regarding the high prevalence of BLV infection in our dairy herds, these findings can explain, at least in part, why high triglycerides levels were associated with bacteriological positive milk samples.

The concentration of total serum proteins was found to be a risk factor for mastitis during the transition period in both logistic regression models (high milk SCC and bacteria-positive milk samples). Supporting this finding, high levels of total serum proteins have been widely related to several infectious diseases that occur during the post-partum period (Piccione et al., 2011).

The levels of total proteins in plasma vary according to changes in the globulin and albumin fractions. Inflammation, infection, and tissue injury lead to the production and release of cytokines by immune cells, resulting in the release of positive acute phase proteins by hepatocytes and a simultaneous decrease in the synthesis of negative acute phase proteins such as albumin (Murata et al., 2004). Among the globulins, there are many important positive acute phase proteins (i.e., $\alpha_{1}$-antitrypsin, $\alpha_{1}$-acid glycoprotein, ceruloplasmin, serum amyloid A, haptoglobin, $\alpha_{2}$-macroglobulin, fibrinogen, complement components (C3 and C4), Creactive protein, and ferritin, in addition to the immunoglobulins) (Kaneko et al., 2008). Globulins are important markers of IMIs in cattle during the peripartum period. Similar to acute 
phase proteins, some of these proteins are considered early indicators of bovine mastitis, are related to the severity of this disease, or are even associated with treatment efficacy (Murata et al., 2004; Pyörälä et al., 2011).

However, acute phase proteins are nonspecific markers of infections; any infection can lead to changes in their serum concentrations, not just infectious mastitis (Murata et al., 2004). In addition, many studies have found associations between mammary gland health and decreased reproductive performance (Hudson et al., 2012). Some studies have also indicated that there is a genetic correlation between mastitis and other sanitary problems in dairy cattle, such as placenta retention, metritis, hypocalcemia, and cystic ovaries (Lin et al., 1989). As mentioned above, cows with compromised immunity, especially during the peripartum period, are more susceptible to mastitis and other diseases (Thompson-Crispi et al., 2012). However, further studies are needed on the associations between distinct acute phase proteins, or groups of acute phase proteins, and illnesses that occur in dairy cows, especially during periparturient period.

The present study also showed that dry cow treatment with anhydrous cephalonium was associated with a lower SCC and lower rate of mastitis pathogen isolation. Corroborating the results of this study, Berry and Hillerton (2002), who used the same antimicrobial at drying off, observed a greater number of new IMIs at calving in untreated animals than in those that received the dry cow therapy.

On the other hand, although antimicrobial treatments can eliminate existing IMIs and prevent new IMIs during the dry period, recent investigations have focused on the public health concerns of overusing antibiotics and have recommended the prudent use of these agents to limit the selection of drug-resistant bacteria and risk of environmental antimicrobial contamination (Berry and Hillerton, 2002). In addition, this practice is still under debate, as it does not protect against infections near calving, the antimicrobial residues in milk can be found depending on the duration of the dry period, and depending of the active principle, it may not be efficient against all types of pathogens responsible for IMIs (Scherpenzeel et al., 2016).
Thus, it has been proposed that the use of the selective dry cow therapy. Nevertheless, it should only be considered in dairy farms that had successfully controlled the major contagious pathogens (i.e. S. aureus and S. agalactiae) and herds with low bulk tank SCC (Cameron et al., 2015). Therefore, the incidence of subclinical mastitis in the majority of Brazilian dairy herds is still high, which indicates that the establishment of large-scale milk quality programs focusing in controlling the major mastitis pathogens is urgently needed (Souza et al., 2016; Busanello et al., 2017), and the high incidence of IMIs may explain why the teat sealant in the present study did not show a significant beneficial effect, as it not eliminate existing IMIs.

\section{CONCLUSIONS}

In the present study, dairy cows with greater concentrations of serum total proteins and triglycerides had higher risk of mastitis in the transition period, in contrast the use of dry cow therapy reduce this risk.

\section{ACKNOWLEDGEMENTS}

This study was supported by the São Paulo State Research Foundation (FAPESP, Process n. 2012/08982-4). K.R.S. (Process no. 2014/06995-7) and F.N.S. (Process no. 2014/23189-4) gratefully acknowledge FAPESP for their fellowships. A.M.M.P.D.L and M.B.H are indebted to the National Council of Technological and Scientific Development (CNPq) for their fellowships.

\section{REFERENCES}

BERRY, E.A.; HILLERTON, J.E. The effect of an intramammary teat seal on new intramammary infections. J. Dairy Sci., v.85, p.2512-2520, 2002.

BERTONI, G.; TREVISI, E. Use of liver activity index and other metabolic variables in the assessment of metabolic health in dairy herds. Vet. Clin. N. Am. Food. A, v.29, p.413-431, 2013.

BRADFORD, B.J.; MAMEDOVA, L.K; MINTON, J.E. et al. Daily injection of tumor necrosis factor- $\alpha$ increases hepatic triglycerides and alters transcript abundance of metabolic genes in lactating dairy cattle. J. Nutr., v.139, p.1451-1456, 2009. 
BUSANELLO, M.; ROSSI, R.S.; CASSOLI, L.D. et al. Estimation of prevalence and incidence of subclinical mastitis in a large population of Brazilian dairy herds. J. Dairy Sci., v.100, p.6545-6553, 2017.

CAMERON, M.; KEEFE, G.P.; ROY, J.-P. et al. Evaluation of selective dry cow therapy treatment following on-farm culture: milk yield and somatic cell count in the subsequent lactation. J. Dairy Sci., v.98, p.2427-2436, 2015.

DELLA LIBERA, A.M.M.P.; SOUZA, F.N.; BATISTA, C.F. et al. Effects of bovine leukemia virus infection on milk neutrophil function and the milk lymphocyte profile. Vet. Res., v.46, p.2, 2015.

DERVISHI, E.; ZHANG, G.; HAILEMARIAM, D. et al. Alterations in innate immunity reactants and carbohydrate and lipid metabolism precede occurrence of metritis in transition dairy cows. Res. Vet. Sci., v.104, p.30-39, 2016.

HUDSON, C.D.; BRADLEY, A.J.; BREEN, J.E.; GREEN, M.J. Associations between udder health and reproductive performance in United Kingdom dairy cows. J. Dairy Sci., v.95, p.3683-3697, 2012.

JAIN, N.C. Scham's veterinary hematology. 4.ed. Philadelphia: Lea \& Febiger, 1986. [1206p.].

KANEKO, J.J.; HARVEY, J.W.; BRUSS, M.L. Clinical biochemistry of domestic animals. 6.ed. Burilington: Academic Press, 2008. [916p.].

KURPIŃSKA, A.K.; JAROSZ, A.; OŻGO, M.; SKRZYPCZAK, W.F. Changes in lipid metabolism during last month of pregnancy and first two months of lactation in primiparous cows - analysis of apolipoprotein expression pattern and changes in concentration of total cholesterol, HDL, LDL, triglycerides. Pol. J. Vet. Sci., v.18, p.291-298, 2015.

KUSHIBIKI, S.; HODATET, K.; SHINGU, H. et al. Alterations in lipid metabolism induced by recombinant bovine tumor necrosis factor-alpha administration to dairy heifers. J. Anim. Sci., v.80, p.2151-2157, 2002.

LEBLANC, S.J.; HERDT, T.H.; SEYMOUR, W.M. et al. Peripartum serum vitamin E, retinol, and betacarotene in dairy cattle and their associations with disease. J. Dairy Sci., v.87, p.609-619, 2004.

LIN, H.K.; OLTENACU, P.A.; VAN VLECK, L.D. et al. Heritabilities of and genetic correlations among six health problems in Holstein cows. J. Dairy Sci., v.72, p.180-186, 1989.

MOYES, K.M.; LARSEN, T.; FRIGGENS, N.C. et al. Identification of potential markers in blood for the development of subclinical and clinical mastitis in dairy cattle at parturition and during early lactation. $J$. Dairy Sci., v.92, p.5419-5428, 2009.
MURATA, H.; SHIMADA, N.; YOSHIOKA, M. Current research on acute phase proteins in veterinary diagnosis: an overview. Vet. J., v.168, p.28-40, 2004.

OLIVER, S.P.; GONZÁLEZ, R.N.; HOGAN, J.S. et al. Microbiological procedures for the diagnosis of bovine udder infection and determination of milk quality. Verona: National Mastitis Council, 2004. 47p.

PICCIONE, G.; MESSINA, V.; MARAFIOTI, S. et al. Changes of some haematochemical parameters in dairy cows during late gestation, post partum, lactation and dry periods. Vet. Zootec., v.58, p.59-64, 2012.

PICCIONE, G.; MESSINA, V.; SCHEMBARI, A. et al. Pattern of serum protein fractions in dairy cows during different stages of gestation and lactation. $J$. Dairy Res., v.78, p.421-425, 2011.

PRESCOTT, S.C.; BREED, R.S. The determination of the number of the body cells in milk by a direct method. J. Infect. Dis., v.7, p.632-640, 1910.

PYÖRÄLÄ, S.; HOVINEN, M.; SIMOJOKI, H. et al. Acute phase proteins in milk in naturally acquired bovine mastitis caused by different pathogens. Vet. Rec., v.168, p.535, 2011.

REZAMAND, P.; HOAGLAND, T.A.; MOYES, K.M. et al. Energy status, lipid-soluble vitamins, and acute phase proteins in periparturient Holstein and Jersey dairy cows with or without subclinical mastitis. J. Dairy Sci., v.90, p.5097-5107, 2007.

SARGEANT, J.M.; LESLIE, K.E.; SHIRLEY, J.E. et $a l$. Sensitivity and specificity of somatic cell count and California mastitis test for identifying intramammary infection in early lactation. J. Dairy Sci., v.84, p.20182024, 2001.

SARIKAYA, H.; PRGOMET, C.; PFAFFL, M.W.; BRUCKMAIER, R.M. Differentiation of leukocytes in bovine milk. Milchwissenschaft, v.59, p.586-589, 2004.

SCHERPENZEEL, C.G.M.; DEN VIJL, I.E.M.; VAN SCHAIK, G. et al. Effect of different scenarios for selective dry-cow therapy on udder health, antimicrobial usage, and economics. J. Dairy Sci., v.99, p.3753-3764, 2016.

SCHUKKEN, Y.H.; WILSON, D.J.; WELCOME, F. et al. Monitoring udder health and milk quality using somatic cell counts. Vet. Res., v.34, p.579-596, 2003.

SCHWEGLER, E.; SCHNEIDER, A.; MONTAGNER, P. et al. Predictive value of prepartum serum metabolites for incidence of clinical and subclinical mastitis in grazing primiparous Holstein cows. Trop. Anim. Health Prod., v.45, p.1549-1555, 2013. 
SEPÚLVEDA-VARAS, P.; WEARY, D.M.; NORO, M.; VON KEYSERLINGK, M.A.G. Transition diseases in grazing dairy cows are related to serum cholesterol and other analytes. PLoS One, 10, e0122317, 2015.

SMITH, B.P. Large animal internal medicine. 5.ed. St. Louis: Elsevier, 2014. 1712p.

SORDILLO, L.M. Nutritional strategies to optimize dairy cattle immunity. J. Dairy Sci., v.99, p.49674982, 2016.

SOUZA, F.N.; MONTEIRO, A.M.; DOS SANTOS, P.R. et al. Antioxidant status and biomarkers of oxidative stress in bovine leukemia virus-infected dairy cows. Vet. Immunol. Immunopathol., v.143, p.162-166, 2011.
SOUZA, F.N.; CUNHA, A.F.; ROSA, D.L.S.O. et al. Somatic cell count and mastitis pathogen detection in composite and single or duplicate quarter milk samples. Pesqui. Vet. Bras., v.36, p.811-818, 2016.

SOUZA, F.N.; SANCHEZ, E.M.R.; HEINEMANN, M.B. et al. The innate immunity in bovine mastitis: recognition of pattern-recognition receptors. Am. J. Immunol., v.8, p.166-178, 2012.

THOMPSON-CRISPI, K.A.; HINE, B.; QUINTON, M. et al. Short communication: Association of disease incidence and adaptive immune response in Holstein dairy cows. J. Dairy Sci., v.95, p.3888-3893, 2012.

TODOVORIĆ, M.J.; DAVIDOVIĆ, V. Changes in white blood pictures and some biochemical parameters of dairy cows in peripartum period and early lactation. Mljekarstvo, v.62, p.151-158, 2012. 